\title{
Ethnicity puts clinical trials to the test
}

Minority enrollment in clinical research tapdances on the periphery of one of the most controversial debates in medicine today: the role of ethnicity in the diagnosis and treatment of disease. The problem, studies suggest, is that not enough minorities participate in clinical studies. UK researchers recently reported that people of South Asian origin are underrepresented in clinical trials there. In the US, the Food and Drug Association is planning to launch new policies to include more women and ethnic minorities in clinical research.

Clinical trials often do not have enough minority participants to give statistically valid conclusions, says Lewis Kuller, professor of epidemiology at the University of Pittsburgh's School of Public Health. "When it comes to minority enrollment in clinical trials, it's not like going to a baseball game and counting the number of people in the stands," Kuller says. "To discover why prostate cancer is more common in blacks, we should look at blacks in the US, blacks in Tobago, blacks in West Africa and compare those groups to whites."

In an effort to standardize results from clinical trials, the FDA in January issued draft guide- lines on collecting race and ethnicity data. The regulations require drug manufacturers to present an analysis of data according to age, gender and race.

In May, Howard University announced plans to create a database of functional mutations linked to diseases common in blacks (Nat. Med. 9, 809; 2003). But race cannot be defined by genes, argues Troy Duster, a sociologist at New York University. "Once we head down this road of collecting genetic material for different groups, we face a real danger of slippage into the notion that there is a set of genetic differences between groups," Duster says. Proponents of the database maintain that it will provide much-needed information about blacks.

Why is minority participation in clinical trials so low? Socioeconomic status is a barrier to all groups when it comes to participating in research, says Olveen Carrasquillo, director of Columbia University's Center for the Health of Urban Minorities. “On a personal level, particularly with Latinos, there is a feeling of lack of trust in the research and there are issues with language," Carrasquillo says.

As world populations mix and marry, ethnic

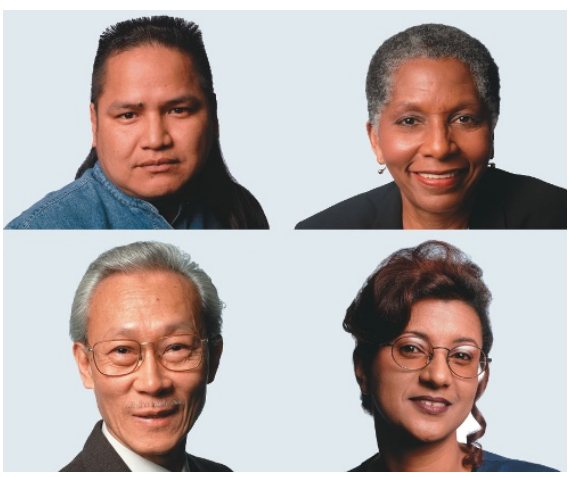

Minority report: Blacks, Latinos, Native Americans and Asians are underrepresented in clinical trials, studies show.

categories may also become less valuable. For example, Tiger Woods is 50\% Thai, $25 \%$ Native American, and 25\% black. "With over 4,500,000 individuals in the latest US census identifying themselves from more than one racial [or] ethnic group," says Howard L. McLeod at the Washington University School of Medicine in St. Louis, Missouri, "the use of race [and] ethnicity categories is becoming of less value."

Amy KErickson, Washington, DC

\section{US ponders law on genetic discrimination}

US lawmakers are edging closer to passing a law that will ban some forms of discrimination based on genetic tests. But the bill does not address other issues that have dogged the field, leaving some observers worried about potential misuse of the tests.

The proposed law—which has cleared a key Senate committee, but has not yet been passed by the full Senate or the House of Representatives_-would make it illegal for employers to use results of genetic tests to hire and fire employees. The bill would also ban insurers from changing group rates based on an individual's test results.

Research associations have lauded the bill, saying it will lift perceived barriers to developing new tests. "A federal law preventing job discrimination would make it easier to recruit subjects into research studies and receive appropriate genetic testing and counseling," says Joann Boughman, executive vice president of the American Society of Human Genetics.

But critics say the proposed legislation does not address several issues, and point to the test for cystic fibrosis as an example of problems that can develop.

A National Institutes of Health (NIH) committee decided in 1997 that couples try- ing to conceive should routinely be offered a test to screen for the mutations that cause cystic fibrosis. Because the mutations do not predict severity of the disease very well, however, the American College of Obstetricians and Gynecologists and the American College of Medical Genetics in 2001 released guidelines for screening. But studies suggest that doctors and patients do not always follow the guidelines, and that some women have had abortions after misinterpreting their test results.

"The example with cystic fibrosis testing is a good case in point," says Kathy Hudson, director of Johns Hopkins University's Genetics and Public Policy Center in Washington, DC. Although the guidelines are comprehensive, she adds, "there's no mechanism for making sure everyone complies, because they are voluntary professional standards."

Some experts say the solution is for the US Food and Drug Administration (FDA) to review each test and enforce its proper use. The FDA does not currently review genetic tests because it considers them a 'service'-not a product-performed by a company (Nat. Med. 9, 147; 2003). Meanwhile, companies such as Myriad Genetics have begun marketing tests directly to consumers, and others are selling clinically unproven tests over the Internet.

Companies and professional societies oppose more regulation of genetic tests. The issue has also become politically charged-a federal advisory committee that recommended FDA oversight was disbanded last year (Nat. Med. 9, 153; 2003), and the newly reconstituted committee held its first meeting this June.

Edward McCabe, chair of the new Secretary's Advisory Committee on Genetics, Health and Society, says the new committee will ask regulatory agencies to explain how they oversee genetic testing, but will not necessarily endorse the old panel's recommendations. McCabe had also chaired the disbanded committee.

In the meantime, professional groups say they will step up their efforts to educate the public and health-care providers. But they acknowledge that, in some cases, education may not solve the whole problem.

"It's a difficult thing to regulate," says Robin Bennett, president of the National Society of Genetic Counselors. "There are mass education efforts going on, but the marketing efforts have been very aggressive, and it's difficult to compete with that."

Erika Check, Washington, DC 